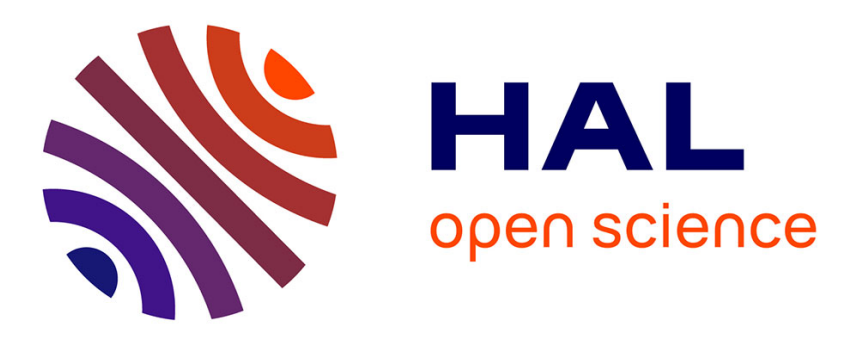

\title{
Virulence diversity among branched broomrape (O. ramosa L.) populations in France
}

Hocine Benharrat, Christian Boulet, Catherine Theodet, Patrick Thalouarn

\section{To cite this version:}

Hocine Benharrat, Christian Boulet, Catherine Theodet, Patrick Thalouarn. Virulence diversity among branched broomrape (O. ramosa L.) populations in France. Agronomy for Sustainable Development, 2005, 25 (1), pp.123-128. hal-00886275

\section{HAL Id: hal-00886275 https://hal.science/hal-00886275}

Submitted on 1 Jan 2005

HAL is a multi-disciplinary open access archive for the deposit and dissemination of scientific research documents, whether they are published or not. The documents may come from teaching and research institutions in France or abroad, or from public or private research centers.
L'archive ouverte pluridisciplinaire HAL, est destinée au dépôt et à la diffusion de documents scientifiques de niveau recherche, publiés ou non, émanant des établissements d'enseignement et de recherche français ou étrangers, des laboratoires publics ou privés. 


\title{
Virulence diversity among branched broomrape (O. ramosa $\mathrm{L}$. populations in France
}

\author{
Hocine Benharrat*, Christian Boulet, Catherine Theodet, Patrick Thalouarn \\ Groupe de Physiologie et de Pathologie Végétales, Faculté des Sciences et des Techniques, 2 rue de la Houssinière, BP 92208, 44322 Nantes Cedex, France
}

(Received 30 June 2004; accepted 13 October 2004)

\begin{abstract}
In France, the obligate root parasite O. ramosa L. (broomrape) causes significant decreases in yields in several crops such as Brassica napus L., Cannabis sativa L. and Nicotiana tabacum L. Over the past few years, the broad distribution and the continuous expansion of this parasitic plant have been pointed out. The diversity of its host plants and the increase in its locations in France led us to investigate the virulence of some $O$. ramosa populations against their potential host plants. Significant variation in their aggressiveness was observed. These results are therefore consistent with the existence of at least two $O$. ramosa pathovars throughout populations scattered in France. A study by PCR of inter-simple sequence repeat (ISSR) of these two populations allowed us to characterize each of them by specific molecular markers.
\end{abstract}

broomrape / hemp / oilseed rape / virulence / pathovar

\section{INTRODUCTION}

Broomrape (Orobanche), a root parasite, is devoid of chlorophyll and must develop a specialized structure, a haustorium, to establish connections with the host vascular tissues and to thereby withdraw water, mineral and organic nutriments. Some species of broomrape are able to parasitize a wide range of agricultural crops $[5,9,23]$ and among them, O. ramosa is one of the most noxious. This is particularly the case in Europe, even if some severe damage has also been reported in other countries such as Australia [23] or Chile [3]. In France, this parasite causes heavy yield losses in several crops, particularly hemp (Cannabis sativa L., Cannabinaceae), oilseed rape (Brassica napus L., Brassicaceae), and tobacco and tomato (Nicotiana tabacum L. and Lycopersicon esculentum Mill, Solanaceae). Its presence was reported in 1893 by Lavergne [14] on tomato and hemp; but for some years, severe infestations have been observed in many locations throughout the country, particularly on hemp and oilseed rape. O. ramosa's biological cycle can differ greatly, depending on the host. For instance, the early stage of subterranean development of the parasite (fixation on the host root) occurs in autumn on Brassica napus L., but in spring on Cannabis sativa L. In spite of the large biological variations in host, soil and climate already underlined, the French $O$. ramosa populations have never been compared for their virulence. Moreover, no information is available concerning the genetic diversity of these $O$. ramosa populations. In order to answer these questions, $O$. ramosa populations collected on different crops in several locations in France should be better characterized.

Orobanche population diversity has already been studied for O. aegyptiaca, O. cumana and $O$. crenata. As morphological characters are not reliable for broomrape population comparisons, in recent years molecular markers have been widely used, particularly RAPD markers [4, 22, 25]. Genomic polymorphism analysis has also been carried out thanks to amplification by polymerase chain reaction (PCR) of inter-simple sequence repeat regions (ISSR) [2, 27]. This strategy was retained in the present study, since the RAPD technique produces less reliable and reproducible bands than ISSR amplification [19, 21].

The aim of this study was to compare the virulence of some French $O$. ramosa populations against their potential host (mainly oilseed rape and hemp) and to characterize them by molecular markers.

\section{MATERIALS AND METHODS}

\subsection{Plant material}

In France, eight $O$. ramosa L. populations were collected, in 2001, from infested Buddleja linleyama F., Brassica napus L., Cannabis sativa L., Fagopyrum esculentum Moench and Nicotiana tabacum L. fields (Tab. I). Ten samples (individual plants) per location were studied. The Brassica napus varieties (Capitol, Complice, Tradition and Lucia) were obtained from

\footnotetext{
* Corresponding author: hocine.benharrat@svt.univ-nantes.fr
} 
Table I. Geographical origin and host plants of O. ramosa L. populations.

\begin{tabular}{lcc}
\hline Population & Origin & Host plant \\
\hline 1 & Sarthe & Cannabis sativa $\mathrm{L}$. \\
2 & Charente-Maritime & Nicotiana tabacum $\mathrm{L}$. \\
3 & Aube & Fagopyrum esculentum Moench \\
4 & Maine et Loire & Cannabis sativa $\mathrm{L}$. \\
5 & Vendée & Brassica napus $\mathrm{L}$. \\
6 & Deux-Sèvres & Brassica napus $\mathrm{L}$. \\
7 & Charente-Maritime & Brassica napus $\mathrm{L}$. \\
8 & Deux-Sèvres & Buddleja linleyama $\mathrm{F}$. \\
\hline
\end{tabular}

CETIOM (Centre Technique Interprofessionnel des Oléagineux Métropolitains, Paris, France) and from SONACOS (Société Nationale de Commercialisation des Semences, Kénitra, Morocco). The Cannabis sativa varieties (Felina 34, Fedora 17, D19 and F56) were obtained from FNPC (Fédération Nationale des Producteurs de Chanvre, Sarthe, France).

\subsection{Molecular analysis}

O. ramosa populations were screened for their molecular markers as follows: total DNA was extracted from $100 \mathrm{mg}$ of frozen tissue (shoot and inflorescence) using the Nucleon Phytopure DNA extraction kit (Amersham, Buckinghamshire, UK).

DNA variations were studied using $(\mathrm{CA})_{6} \mathrm{RG}$ primer, synthesized at ESGS, Cybergene Group, Evry, France. ISSR amplifications were performed in $25 \mu \mathrm{L}$ of mixture containing $20 \mathrm{ng}$ of template DNA, $100 \mu \mathrm{M}$ of each dNTP, $4 \mu \mathrm{M}$ of primer, $2.5 \mu \mathrm{L}$ of $10 \mathrm{X}$ buffer (Appligene, Illkirch, France) and $0.5 \mathrm{U}$ of Taq polymerase (Appligene) in a PCR thermal cycler (Perkin-Elmer Cetus, Norwalk, USA). The ISSR amplification program was as follows: initial denaturation for $1 \mathrm{~min}$ at $94^{\circ}, 35$ cycles of $1 \mathrm{~min}$ at $94^{\circ}, 1 \mathrm{~min}$ at $50^{\circ}$ and $4 \mathrm{~min}$ at $72^{\circ}$ and a final step for $7 \mathrm{~min}$ at $72^{\circ}$. PCR products were separated by electrophoresis in $1.5 \%$ agarose gel, stained with ethidium bromide. The replicability of the amplification was checked five times.

\subsection{Screening under greenhouse conditions}

All experiments were conducted in 1.3-liter pots filled with soil mixture (1: sand, 1: compost, 1: soil), mixed with $10 \mathrm{mg}$ $O$. ramosa seeds collected from oilseed rape or hemp infested fields. The pots were watered and kept in the dark for a week at $20^{\circ}$ to allow preconditioning of the Orobanche seeds. Subsequently, three Brassica napus or Cannabis sativa seeds were sown in the pots. After emergence, seedlings were thinned to one plant per pot. Plants were grown under a 16-hour photoperiod $\left(300 \mu \mathrm{mol} \mathrm{m} \mathrm{m}^{-2} \mathrm{~s}^{-1}\right.$ PAR). Host plants were harvested 9 weeks after sowing. O. ramosa shoots were counted and the host plant root system washed before screening of all fixed tubercles. All experiments on broomrape infestation were conducted in three pots and replicated three times.

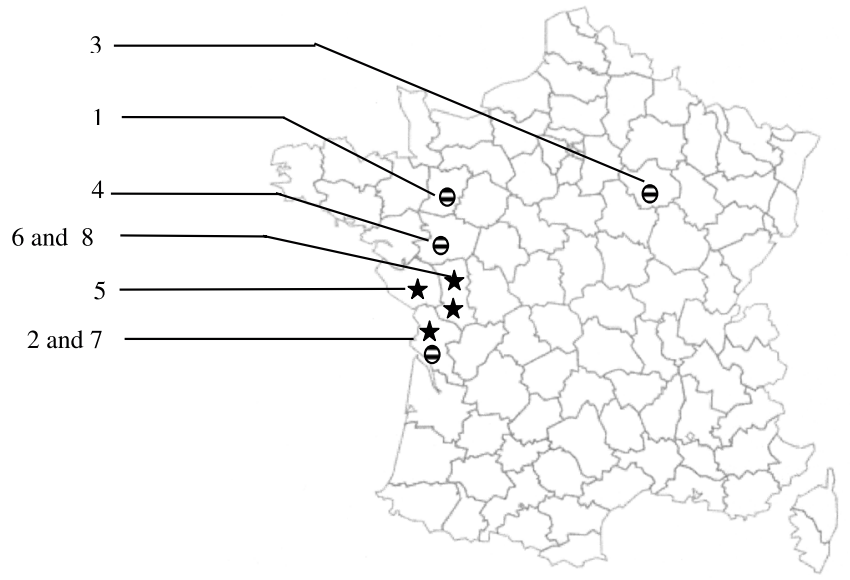

Figure 1. Eight $O$. ramosa populations collected from different locations in France. 1: Sarthe; 2: Charente-Maritime; 3: Aube; 4: Maine et Loire; 5: Vendée; 6: Deux Sèvres; 7: Charente-Maritime; 8: DeuxSèvres ( $\star$ : in oilseed rape fields, $\ominus$ : in other crop fields).

\section{RESULTS}

\subsection{Virulence of $O$. ramosa populations collected in France}

The virulence of two $O$. ramosa populations was tested against their potential host plants: $C$. sativa and $B$. napus. Seeds of populations A and B were collected in Vendée from an affected oilseed rape field and in Sarthe from an infested hemp field, respectively (Fig. 1). The two locations are $250 \mathrm{~km}$ apart.

The resistance of four oilseed rape varieties (Capitol, Complice, Lucia and Tradition) and four hemp varieties (Fedora 17, Felina 34, F 56 and D 19) to O. ramosa populations was evaluated by counting Orobanche fixations on host root systems and emerged broomrape. Both oilseed rape and hemp varieties were susceptible to the $O$. ramosa populations collected in oilseed rape fields (population A), but the number of broomrape attachments on root systems was always higher on oilseed rape varieties. For instance, 7 to 22 attachments per plant were counted, as opposed to only 0.3 to 4.9 for the hemp varieties (Fig. 2). All the oilseed varieties, while differently susceptible, supported emerged broomrape, in contrast to hemp varieties: for three varieties out of four, no broomrape shoot emergence was observed. The most susceptible oilseed rape varieties were Capitol and Tradition, whereas the hybrid lines, Complice and Lucia, appeared more resistant. Given the number of attachments and the degree of emergence, this screening indicated that oilseed rape was always more susceptible than hemp to O. ramosa population A. Moreover, three hemp varieties out of four supported a significant number of necrosed tubercles, whose number was above those of viable attachments in the case of Fedora 17 and D19. It can therefore be concluded that $O$. ramosa population A was more aggressive for oilseed rape than for hemp.

In contrast, results obtained from infestation by $O$. ramosa population B collected on hemp fields were greatly different, since the number of fixations and emergences were both significantly 


\section{O. ramosa population $A$ : number of total broomrape attachments/plant}

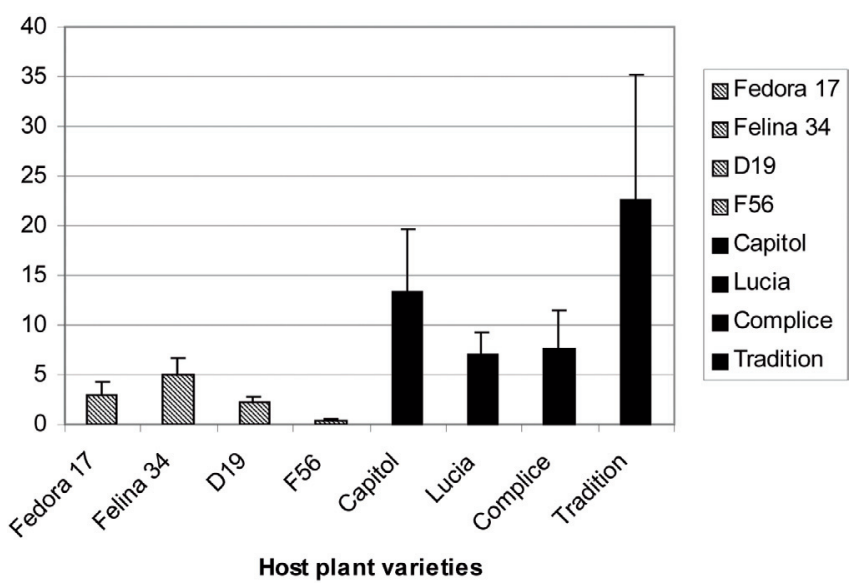

Figure 2. Infestation of four hemp varieties and four oilseed varieties by $O$. ramosa population A. Results represent the mean total number of broomrape fixations per plant + /-SE of three experiments. hemp varieties oilseed varieties.

higher with hemp varieties. For instance, with population $B$, the susceptibility of hemp varieties varied from 18 to 33 attachments per plant for D19 and Fedora17, respectively (Fig. 3). When the four oilseed varieties were infested, in spite of only 3 fixations per plant, $O$. ramosa completed its life cycle with emerged shoots as was, of course, the case with the hemp varieties.

To summarize, this study showed that, in France, the susceptibility of the two host plant species screened varies according to the $O$. ramosa populations. Thus, oilseed rape varieties appear to be susceptible to the $O$. ramosa population collected in colza fields and more resistant to the $O$. ramosa population originating from hemp fields, and vice versa for the hemp varieties. Based on these results, these two $O$. ramosa populations could be considered as two distinct pathovars (A and B, respectively).

\subsection{Identification of the two $O$. ramosa pathovars by molecular markers}

The importance of virulence differences between the two $O$. ramosa populations led us to check for morphological features in an attempt to clearly identify them in the fields. However, no reliable morphological trait to differentiate them has been pointed out. To overcome these identification difficulties, specific molecular markers obtained from the ISSR-PCR technique, previously used for an $O$. ramosa Sudan populations study [1] and Orobanche subsection Minores species [2] were searched for. The two $O$. ramosa pathovars were studied by analyzing electrophoretic patterns obtained from inter-simple sequence repeat amplification. Therefore eight populations collected from different host plants (Tab. I) in different areas (Fig. 1) were compared. The use of the anchored primer, (CA) ${ }_{6} \mathrm{RG}$, revealed a genetic polymorphism which allowed the characterization of two groups of populations which each corresponds to a pathovar (A or B). Each of them can be identified

\section{O. ramosa population $B$ : number of total broomrape attachments/plant}

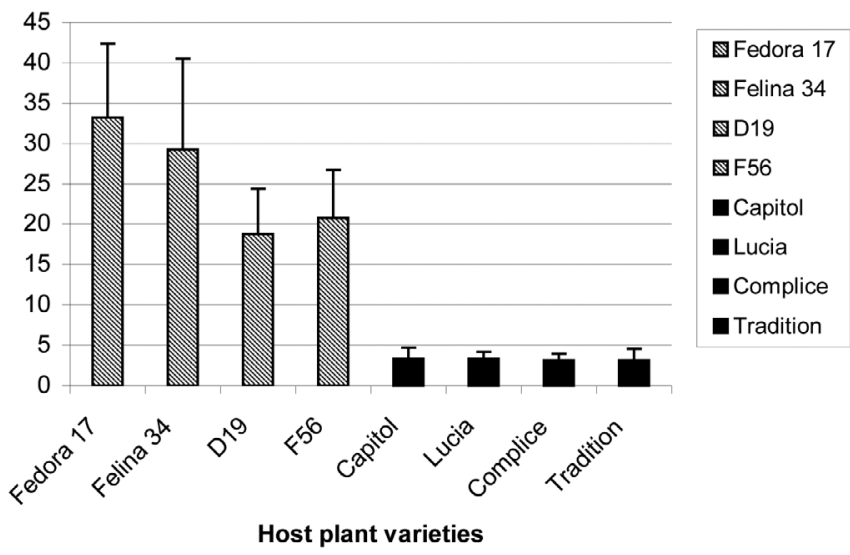

Figure 3. Infestation of four hemp varieties and four oilseed varieties by $O$. ramosa population $\mathrm{B}$. Results represent the mean total number of broomrape fixations per plant $+/-$ SE of three experiments. hemp varieties $\square$ oilseed varieties. by specific markers: two specific bands (1200 and $1400 \mathrm{bp}$ ) for the pathovar A and two others, 1300 and 1350 bp (Fig. 4), for the pathovar B. The study of ten samples per population revealed a similar electrophoretic pattern for all specimens.

The pathovar B's specific molecular markers (lane 1) (Fig. 4) are present on the electrophoretic pattern of three other $O$. ramosa populations (lanes 2, 3 and 4). These four $O$. ramosa populations (characterized by the same markers) had been collected in localities widely distributed all over the area of sample collection (Fig. 1). They were fixed on three different hosts (Cannabis sativa L., Nicotiana tabacum L. and Fagopyrum esculentum Moench) which belong to the Cannabinaceae, Solanaceae and Polygonaceae families, respectively. Two $O$. ramosa populations (Tab. I) collected on the same host plant, C. sativa, in areas (Sarthe and Maine et Loire) more than $100 \mathrm{~km}$ apart, exhibited the same electrophoretic profile (Fig. 4).

The four other $O$. ramosa populations were identified by two other specific markers (1200 and $1400 \mathrm{bp}$ ). Three of them were collected in oilseed rape fields, while the fourth was parasitized Buddleja linleyana F. (Tab. I) on the border of oilseed rape fields. Thus, those populations are more closely located westward of the sampling area. In the Charente-Maritime region two populations (Fig. 1) collected less than ten $\mathrm{km}$ from each other, on different host plants (tobacco and oilseed rape), were demonstrated to carry different molecular markers, specific to each pathovar (lane 2 and lane 7, Fig. 4).

\section{DISCUSSION}

In France, O. ramosa distribution is broad and in continuous extension. In spite of the wide range of infested crops (tobacco, oilseed rape and hemp), neither molecular characterization nor virulence variation had been undertaken up to now. Thanks to 


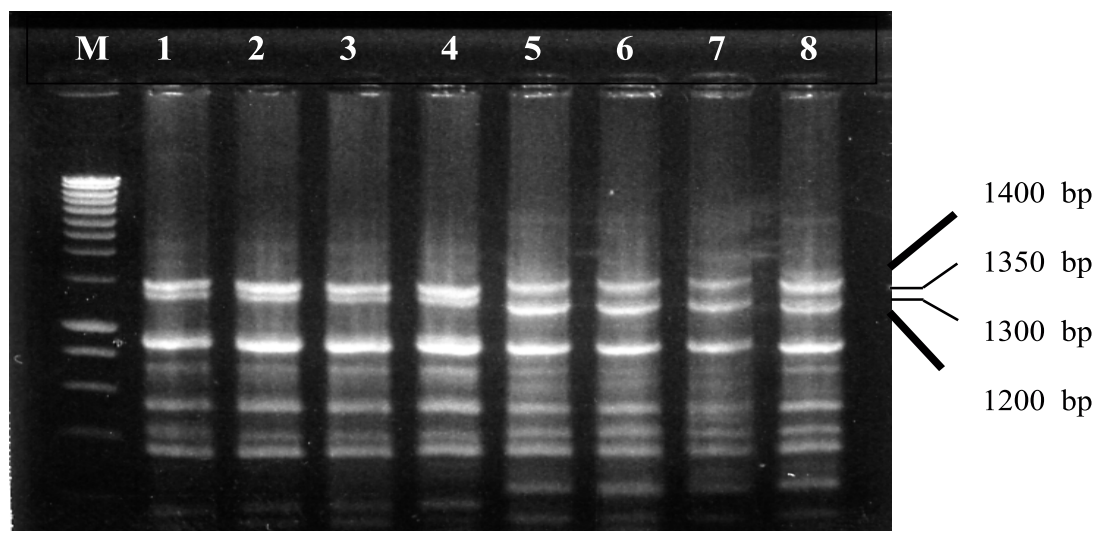

Figure 4. Inter-simple sequence repeat (ISSR) fingerprints of eight French $O$. ramosa populations using the primer (CA)6RG. M: molecular markers, lane 1 to 8: O. ramosa populations fixed on different host plants. Lane 1: Cannabis sativa L., lane 2: Nicotiana tabacum L., lane 3: Fagopyrum esculentum Moench, lane 4: Cannabis sativa L., lane 5 to 7: Brassica napus L., lane 8: Buddleja linleyama $\mathrm{F}$.

Pathovar A molecular markers

Pathovar B molecular markers.

the ISSR method, this study revealed a genetic polymorphism which discriminated the different French populations into two groups. Each of them can be characterized by two specific molecular markers. Our results report that within each group, a distinct pathovar was clearly identified. Such virulence variability among $O$. ramosa populations has until now never been pointed out, even if the existence of "race" [6] has been supposed (but not characterized). Therefore, this raises the question if all the same groups of populations develop the same virulence with respect to their hosts. In this case, the molecular markers identified in this study could be associated with each pathovar. On the contrary, if each population expresses a different pathogenicity, there would thus exist, in France, several other $O$. ramosa pathovars apart from those defined in this study. With the aim of confirming this hypothesis, a significant virulence study of all those populations is currently being carried out.

$O$. ramosa diversity appears not to be correlated with geographical location. Thus, in the Charente-Maritime region, two populations characterized by distinct molecular markers were collected in two areas less than $10 \mathrm{~km}$ apart, whereas $O$. ramosa specimens which exhibit the same ISSR pattern and host spectrum were collected from locations more than $100 \mathrm{~km}$ apart (the Sarthe and Maine et Loire regions). These results agree with those of Zeid et al. [30], Roman et al. [26] and Benharrat et al. [2], who compared $O$. crenata and $O$. hederae populations in Egypt, Spain and Israel, and France, respectively.

In the case of $O$. ramosa, the occurrence of molecular marker diversity does not seem to be strictly linked to the specificity of the host plant since $O$. ramosa belonging to the pathovar B group was collected on various crops such as C. sativa, N. tabacum and $F$. esculentum, members of three families, the Cannabinaceae, Solanaceae and Polygonaceae, respectively. However, pathovar A group specimens were mostly found to be associated with oilseed rape. In only one case, specimens were collected on another host plant, Buddleya linleyama F (Buddlejaceae). The host root system was carefully examined and O. ramosa was found connected to its roots. Its localization, on the border of oilseed rape fields, suggests a contamination by $O$. ramosa seed dissemination. While Musselman and Parker [18] indicated that the host plant influences $O$. ramosa variability, Paran et al. [22] did not observe a similar correlation for $O$. aegyptiaca and $O$. crenata. On the other hand, an ISSR study of $O$. hederae populations [1] has shown that this monospecific parasitic plant exhibits different genetic patterns according to its geographical location.

The two $O$. ramosa pathovars, characterized by their host plant range, differ, of course, in their pathogenicity against a host. However, a host susceptibility variability exists among the lines and hybrids. Generally speaking, hybrids are more resistant, as also observed by Zehhar et al. [29] who studied interactions between fifteen oilseed varieties and an $O$. ramosa population originating from Sudan. If this population was noted as being less aggressive than the French populations, the same resistance range of three oilseed rape varieties, shared in these two studies, was observed, suggesting that their general resistance level, depending on several genes, remains expressed whatever the pathovar.

The finding of two pathovars among $O$. ramosa collected in France raises the question of how closely they are related; for instance, according to their geographical origin and their date of introduction into this country. The extension of $O$. ramosa in Maine et Loire, on hemp fields, is directly associated with hemp seed importation from Turkey, between 1920 and 1939 [20]. However, the presence of this parasite species has been known in France since at least the XIX century and was described on hemp in 1842 and 1857 by Holandre [10] and Godron [7], respectively. Le Maout and Ducaines [15] observed it in tobacco fields in 1876 , while Lavergne [14] announced its presence on tomatoes some years later (1893). The latter also described a broomrape specimen on Brassica rapa L. in Lot et Garonne and identified this specimen as $O$. speciosa, already known in Germany on Brassica napus L. and Brassica capitata $\mathrm{L}$.

In Europe, oilseed rape domestication started in the early Middle Ages, while commercial plantings have been known 
since the XVIth century. After the Second World War, oilseed rape production increased considerably, but $O$. ramosa extension, on Brassica napus fields in France, has only been observed for the last ten years. As O. ramosa pathovar A appears to be strictly located where oilseed rape is grown, its extension could coincide with a new event for which two hypotheses could be proposed. This pathovar was introduced with contaminated seeds (for instance, from Turkey, between 1920 and 1939) or it spontaneously burst out after a change in the genetic and phenotypic characteristics of the oilseed rape varieties grown in France. Several changes have occurred over the two last decades in France with the introduction and the intensive culture of lines with low content in glucosinolates which are known to constitute a defence system in cruciferous plants toward pests and diseases. It has been shown that glucosinolates are induced by different defence pathways in Arabidopsis ecotypes [16]. Besides, it is known that lines and hybrids are almost exclusively grown in France, instead of populations in most other countries.

It has been shown (Boulet C., pers. comm.) that broomrape pathovar A could parasitize and carry out its life cycle on weeds which are strictly limited in their expansion in oilseed rape areas (Senecio vulgaris L., Ammi majus L. and Galium aparine L.). It is therefore expected that these wild plants have served as "tank" plants, increasing the broomrape seed-bank in the soil, until the oilseed rape introduction in these areas, which led to a burst in Orobanche infestation. Such an observation of an outburst of broomrape has been made with $O$. foetida Poiret, in Tunisia [12]. This broomrape was initially known as a parasite of wild plants until its recent development on Faba bean, a crop on which Orobanche is more aggressive than on other legumes [13].

If variation in aggressiveness has been demonstrated in different Orobanche species such as $O$. cumana $[8,17,28]$ and $O$. crenata [11], no similar study had been carried out for $O$. ramosa prior this work, which revealed large differences in virulence between two French populations. The undoubted identification of a pathovar, particularly virulent and widespread in oilseed rape fields, is of great interest for further studies on Orobanche control.

Acknowledgements: We thank G. Williams for critical reading of the manuscript.

\section{REFERENCES}

[1] Benharrat H., Theodet C., Veronesi C., Thalouarn P., Broomrape identification using simple sequence repeat (ISSR). Application to Trionychon Wallr and Osproleon section species, in: Fer A., Thalouarn P., Joel D.M., Musselman L.J., Parker C., Verkleij J.A.C. (Eds.), Proc. of the 7th International Parasitic Weed Symposium, Nantes, France, 2001, pp. 79-80.

[2] Benharrat H., Veronesi C., Theodet C., Thalouarn P., Orobanche species and population discrimination using inter simple sequence repeat (ISSR), Eur. Weed Res. 42 (2002) 1-6.

[3] Diaz J., Norambuena H., Parasitism and phenology of Orobanche ramosa L. on tomato, in: Fer A., Thalouarn P., Joel D.M., Musselman L.J., Parker C., Verkleij J.A.C. (Eds.), Proc. of the 7th International Parasitic Weed Symposium, Nantes, France, 2001, p. 47.
[4] Gagne G., Roeckel-Drevet P., Grezes-Besset B., Shindrova P., Ivanov P., Grand-Ravel C., Vear F., Tourvieille de Labrouhe D., Charmet G., Nicolas P., Study of the variability and evolution of Orobanche cumana populations infesting sunflower in different European countries, Theor. Appl. Genet. 96 (1998) 1216-1222.

[5] Gibot-Leclerc S., Tuquet C., Corbineau F., Arjaure G., Sallé G., New insights on Orobanche ramosa L. parasiting oilseed rape in western part of France, in: Fer A., Thalouarn P., Joel D.M., Musselman L.J., Parker C., Verkleij J.A.C. (Eds.), Proc. of the 7th International Parasitic Weed Symposium, Nantes, France, 2001, p. 45.

[6] Gibot-Leclerc S., Brault M., Salle G., L'Orobanche rameuse. La menace s'aggrave pour le colza, le chanvre et le tabac, Phytoma 561 (2003) 9-12.

[7] Godron J.J., Flore de Lorraine, Gimblot, Raybois et Cie, Nancy, France, 1857.

[8] Gonzalez-Torres R., Jimenez-Diaz R.M., Melero-Vera J.M., Distribution and virulence of Orobanche cernua in sunflower crops in Spain, Phytopathol. Z. 104 (1982) 78-89.

[9] Haidar M.A., Bibi W., Sidahmed M.M., Response of branched broomrape (Orobanche ramosa) growth and development to various soil amendments in tomato, Crop Prot. 22 (2003) 291-294.

[10] Holandre D.A., Flore de Moselle, Metz, France, 1842.

[11] Joël D.M., Understanding the biology of broomrapes is required for manipulation of host resistance, in: Cubero J.I., Moreno M.T., Rubiales D., Sillero J. (Eds.), Resistance to Orobanche: the state of the art, Junta de Andalucia, Spain, 1999, pp. 91-97.

[12] Kharrat M., Halila M.H., Linke K.H., Haddar T., First report of Orobanche foetida Poiret on faba bean in Tunisia, FABIS Newslett. 30 (1992) 46-47.

[13] Kharrat M., Halila M.H., Beniwal S.P.S., Parasitism of two faba varieties as affected by different seed inoculum levels of Orobanche crenata and $O$. foetida, in: Pieterse A.H., Verkleij J.A.C., ter Borg S.J. (Eds.), Biology and management of Orobanche, Proc. of the Third International Workshop on Orobanche and related Striga Research Amsterdam, The Netherlands, 1994, pp. 342-348.

[14] Lavergne G., Contribution à l'histoire des Orobanches, in: Coulet C. (Ed.), Montpellier, France, 1893, pp. 1-67.

[15] Le Maout E., Decaisne J., Traité général de botanique, Didot et Cie (Eds.), Paris, France, 1876.

[16] Mikkelsen M.D., Petersen B.L., Glawischnig E., Jensen A.B., Andreasson E., Halkier B.A., Modulation of CYP 79 genes and glucosinolates profiles in Arabidopsis by defence signaling pathways, Plant Physiol. 131 (2003) 298-308.

[17] Musselman L., Taxonomy of Orobanche, in: Biology and control of Orobanche, ter Borg S.J. (Ed.), Proc. Workshop on Biology and Control of Orobanche, Wageningen, The Netherlands, 1986, pp. 2 20.

[18] Musselman L.J., Parker C., Preliminary host ranges of some strains of economically important broomrapes (Orobanche), Econ. Bot. 36 (1982) 270-273.

[19] Nagaoka T., Ogihara Y., Applicability of inter-simple sequence repeat polymorphism in wheat for use as DNA markers in comparison to RFLP and RAPD markers, Theor. Appl. Genet. 94 (1997) 597-602

[20] Nicot A., La culture du chanvre en France, problèmes techniques et économiques posés par l'Orobanche, in: Association de Coordination Technique Agricole (Ed.), Paris, France, 1959, pp. 5-8.

[21] Qhian W., Ge S., Honk D.Y., Genetic variation within and among population of wild rice Oryza granulata from China detected by RAPD and ISSR markers, Theor. Appl. Genet. 17 (2001) 440-449.

[22] Paran I., Gidoni D., Jacobsohn R., Variation between and within broomrape (Orobanche) species revealed by RAPD markers, Heredity 78 (1997) 68-74. 
[23] Parker C., Riches C.R., Orobanche species: The broomrapes, in: Parasitic Weeds of World, Biology and Control CAB International (Eds.), Wallingford, UK, 1993, pp. 111-164.

[24] Parker C., The present state of the Orobanche problem, in: Pieterse A.H., Verkleij J.A.C., ter Borg S.J. (Eds.), Biology and management of Orobanche, Proc. of the Third International Workshop on Orobanche and related Striga Research, Amsterdam, The Netherlands, 1994, pp. 17-26.

[25] Roman B., Alfaro C., Torres A.M., Moreno M.T., Satovic Z., Pujadas A., Rubiales D., Genetic relationship among Orobanche species as revealed by RAPD analysis, Ann. Bot. 91 (2003) 637-664.

[26] Roman B., Rubiales D., Torres A.M., Cubero J.I., Satovic Z., Genetic diversity in Orobanche crenata populations from Southern Spain, Theor. Appl. Genet. 103 (2001) 1108-1114.
[27] Roman B., Satovic Z., Rubiales D., Torres A.M., Cubero J.I., Katzir N., Joel D.M., Variation among and within populations of parasitic weed Orobanche crenata from Spain and Israel revealed by inter simple sequence repeat markers, Phytopathology 92 (2002) 1262 1266.

[28] Vranceanu A.V., Pirvu N., Stoenescu F.M., Pacureanu M., Some aspects of the interaction Helianthus annulus L./Orobanche cumana, and its implications in sunflower breedings, in: ter Borg S.J. (Ed.), Proc. Workshop on Biology and Control of Orobanche, Wageningen, The Netherlands, 1986, pp. 181-189.

[29] Zehhar N., Labrousse P., Arnaud M.C., Boulet C., Study of resistance to Orobanche ramosa in host (oilseed rape and carrot) and nonhost (maize) plants, Eur. J. Plant Pathol. 109 (2003) 75-82.

[30] Zeid M., Madkour M., Koraiem Y., Nawar A., Soliman M., Zaitoun F., Molecular studies on Orobanche, J. Pathol. 145 (1997) 351-355. 